\title{
EFEK CAPITAL ADEQUACY RATIO, NON PERFORMING FINANCING, DAN OPERATIONAL EFFECIENCY RATIO ATAS RETURN ON ASSET PADA BANK UMUM SYARIAH MILIK NEGARA
}

\author{
Achmad \\ Pascasarjana Universitas Islam Negeri (UIN) Sunan Kalijaga Yogyakarta \\ Email : achmad03P@gmail.com
}

\begin{abstract}
Abstrac: The purpose of this study was to analyze the effect of the level of bank performance as measured by the Capital Adequacy Ratio (CAR), Non Performing Financing (NPF), and Operational Efficiency Ratio (OER) on Return On Assets (ROA) in state-owned Islamic banks. The data analysis technique uses panel data regression analysis with a test tool in the form of Eviens 07 . From the results of data analysis it can be concluded that partially that the capital adequacy ratio and non-performing ratio do not have a significant effect on return on assets. Whereas operational efficiency ratio has a significant effect on return on assets. Even so, the value of coefficients of the variable capital adequacy ratio and non-performing financing shows that there is no match between the theory and the results obtained. Only operational efficiency ratio variables are in line with the theory. Each theory is explained, when the capital adequacy ratio rises, it will increase return on assets. But the results obtained othervise, each increase in capital adequacy ratio of $1 \%$ actually decreases return on assets by $0.5285 \%$. The results of the coefficient of non-performing financing are also the opposite. Which should when non-performing rises, return on assets falls. But the coefficient value produces different, the increase in non-performing financing by $1 \%$ actually returns on assets rose by $2.5256 \%$. Then the operational efficiency ratio which should increase will reduce return on assets. in fact, the different results obtained were an increase in the operational efficiency ratio of $1 \%$, thus reducing return on assets by 9.1416\%.
\end{abstract}

Abstrak:. Tujuan dari penelitian ini adalah untuk menganalisis pengaruh tingkat kinerja bank yang diukur dengan Capital Adequacy Ratio (CAR), Non Performing Financing (NPF), dan Operational Effeciency Ratio (OER) terhadap Return On Asset (ROA) pada bank umum syariah milik negara. Teknik analisis data menggunakan analisis regresi data panel dengan alat bantu uji berupa Eviews 07. Dari hasil analisis data dapat disimpulkan bahwa secara parsial bahwa capital adequacy ratio dan non performing ratio tidak memiliki pengaruh signifikan terhadap return on asset. Sedangkan operational effeciency ratio memiliki pengaruh yang signifikan terhadap return on asset. Meskipun begitu, nilai koefisiensi dari variabel capital adequacy ratio dan non performing financing menunjukkan bahwa tidak adanya terdapat kesesuaian antara teori dan hasil yang di dapatkan. Hanya variabel operational effeciency ratio yang sejalan dengan teori. Masing-masing dalam teori dijelaskan, ketika capital adequacy ratio naik maka akan meningkatkan return on asset. Namun hasil yang diperoleh sebaliknya, setiap kenaikan capital adequacy ratio $1 \%$ justru menurunkan return on asset sebesar 0,5285\%. Hasil koefisien non performing financing juga sebaliknya. Yang mana seharusnya ketika non performing naik maka return on asset turun. Namun nilai koefiesien menghasilkan berbeda, kenaikan non performing financing sebesar 1\% justru return on asset naik sebesar 2,5256\%. Kemudian operational effeciency ratio yang seharusnya kenaikannya akan menurunkan return on asset. justru hasil berbeda yang diperoleh yaitu peningkatan operational effeciency ratio sebesar 1\% maka menurunkan return on asset sebesar $9,1416 \%$.

Kata Kunci: Capital Adequacy Ratio; Non Performing Financing; Operational Effeciency Ratio; Return On Asset

\section{Pendahuluan}

Tidak dipungkiri lagi, bahwa perkembangan perbankan syariah khususnya di Indonesia terus mengalami peningkatan setiap tahunnya, bahkan kemunculan perbankan syariah sebagian besar merupakan hasil konversi dari bank konvensional yang mencoba untuk menjaring nasabah sebanyakbanyaknya. Walapun pada awal pendiriannya sempat diragukan, dengan beranggapan bahwa peniadaan mekanisme Interest free tidak bisa, bahkan tidak mungkin untuk bisa diterapkan, serta bagaimana ia kelak akan membiayai operasionalnya. ${ }^{1}$ Akan tetapi, keberadaannya terus menjamur di setiap wilayah di Indonesia.

Ketika terjadi krisis moneter tahun 1998 yang dimulainya dengan depresiasi yang drastis Bath Thailand, Indonesia merupakan salah-satu negara terparah terkena dampaknya. Kurs rupiah terjun bebas, mulai dari Rp. 2.400 per USD pada awal tahun 1997 menjadi Rp. 16.000 per USD bulan juni 1998. Sementara itu, tagihan bank dalam bentuk kredit valuta asing mengalami kenaikan, kenaikan

1 Celine dan Seri (2016) dalam Nur Yasin, Hukum

Ekonomi Islam (Malang: UIN Malang Press, t.t.), 31. 
ini menyebabkan kreditur tidak mampu membayar kembali hutangnya. Akibat dari pada itu, bank kesulitan mempertahankan likuiditasnya, bahkan kesulitan bank diperparah oleh penabung, deposan, dan kreditur yang mulai menarik uangnya, sehingga Capital Adequacy Ratio (CAR) negatif dan mengalami kerugian negative spread. Pada bulan bulan November otoritas moneter terpaksa harus melikuiditasi 16 Bank Umum Swasta Nasional, setelah itu membekukan operasional 7 bank lagi, serta pada bulan April 1998 men-take over 7 bank lainnya. ${ }^{2}$ Bank tidak mampu mempertahankan kinerja keuangannya. Akibatnya, perbankan yang menjadi salah-satu tonggak perekonomian, menyebabkan ekonomi Indonesia sangat begitu anjlok setelah 32 tahun terakhir.

Akan tetapi, di saat banyak bank di Indonesia mengalami kegoncangan yang luar biasa dan terpaksa harus ditutup, ternyata Bank Muamalat Indonesia (BMI) mampu berdiri kokoh. Bank yang dalam pengoprasiannya berdasarkan prinsipprinsip syariah ini sanggup untuk bertahan. Produk yang bervariasi seperti halnya Murabahab Financing yang tidak terpengaruh oleh fluktuasi BI rate, sehingga dampak dari kenaikan BI rate tidak berpengaruh buruk pada sektor riil yang menggunakan jenis pembiayaan ini. Pada saat krisis berlangsung, secara faktual Bank Muamalat merupakan salah-satu bank yang dikategorikan sehat, karena mempunyai Capital Adequacy Ratio dengan kategory A, yaitu $4 \%$ ke atas. ${ }^{3}$ Ketika sebuah bank tersebut dianggap sehat, maka dapat dikatakan bahwa kinerja keuangan perbankan itu baik, baik dari segi penghimpunan ataupun dari penyalurannya.

Dalam melihat seberapa sehat kondisi suatu bank, dapat dilihat dari profitabilitas bank tersebut. Darmono menjelaskan bahwa konsep profitabilitas digunakan sebagai indikator kinerja yang sangat fundamental pada suatu badan usaha dalam hal ini bank. Dimensi yang terdapat pada profitabilitas mempunyai hubungan kausalitas terhadap bank itu sendiri. Kemudian ia mengatakan bahwa kausalitas ini menunjukkan bahwa, ketika kinerja manajemen

\footnotetext{
2 Widjanarto (2003) dalam Khotibul Umam, Perbankan Syariah, Dasar-dasar dan Dinamika Perkembangannya di Indonesia, 9.

${ }^{3}$ Khotibul Umam, 9.

4 Darmono, Manajemen Keuangan, Berbasis Balanced Scorecard, Pendekatan Teori, Kasus, dan Riset Bisnis, kedua (Jakarta: Bumi Aksara, 2011), 110.

5 Sofyan Syafri Harahap, Analisis Kritis Atas Laporan

Keuangan (Jakarta: Rajagrafindo, 2007), 305.

6 Suryani, "Analisis Pengaruh Financing To Deposit Ratio (FDR) Terhadap Profitabilitas Perbankan Syariah di Indonesia" 19 (1) (Mei 2011): 47-74,
}

bank yang diukur menggunakan dimensi-dimensi profitabilitas dalam kondisi baik, maka akan berdampak positif terhadap keputusan Investor (Penabung, Deposan). Demikian juga yang nantinya akan berdampak pada keputusan pihak bank dan kaitannya dalam hal penyaluran dana (financing). ${ }^{4}$

Profitabilitas merupakan tolak ukur yang tepat dalam mengukur kinerja pada suatu bank. Ukuran profitabilitas yang banyak digunakan adalah Return On Asset (ROA). ROA ini merupakakan rasio yang menunjukkan seberapa kemampuan bank dalam memeperoleh laba bersih yang diukur dengan keseluruhan nilai akiva. ${ }^{5}$ Dalam mengukur efektifitas bank dalam menghasilkan income, tentu ROA sangat penting digunakan sebagai tolak ukur. Oleh sebab itu, semakin besar ROA menunjukkan kinerja suatu perbankan semakin baik, karena tingkat return yang semakin besar, ${ }^{6}$ sehingga hal ini juga terjadinya bank tersebut dalam kondisi bermasalah akan sangat kecil.

Profitabilitas yang digunakan sebagai indikator kinerja bank memiliki beberapa rasio keuangan yang ikut andil dalam mempengaruhi profitabilitas bank itu sendiri. Salah-satu rasio yang mempengaruhi ialah Capital Adequacy Ratio (CAR). CAR adalah rasio permodalan yang menunjukkan kemampuan bank dalam menyediakan dana untuk keperluan pengembangan usaha dan menampung kemungkinan resiko kerugian yang diakibatkan dalam operasional bank. ${ }^{7}$ Rasio kecukupan modal ini berfungsi menampung resiko kerugian yang kemungkinan dihadapi oleh bank. Semakain tinggi CAR maka semakin baik kemampuan bank tersebut untuk menanggung resiko dari setiap kredit/aktiva produkstif yang beresiko. ${ }^{8}$ Jika nilai CAR tinggi maka bank tersebut mampu membiayai kegiatan operasional dan memberikan kontribusi yang cukup besar bagi profitabilitas.

Kemudian Non Performing Financing yang juga dapat mempengaruhi profitabilitas bank. Non Performing Financing (NPF) merupakan rasio keuangan yang menunjukkan total pembiayaan bermasalah dalam bank. Ratio tersebut mengukur

http://dx.doi.org/10.21580/ws.19.1.212 Volume 19, Nomor 1.

7 Tarmizi dan Kartiko dalam Lina Nur Hidayat, "Pengaruh Kecukupan Modal (CAR), Pengelolaan Kredit (NPL), dan Likuiditas Bank (LDR) Terhadap Probabilitas Kebangkrutan Bank (Studi Pada Bank Umum Swasta Devisa Yang Tercatat di BEI Tahun 2009-2013)" 12 (1) (t.t.) Volume 12, Nomor 1, 2015.

8 Ikatan Bankir Indonesia (IBI), Manajemen Kesehatan Bank Berbai Resiko, Pertama (Jakarta: Gramedia Pustaka Utama, 2016) Gramedia Pustaka Utama, Jakarta. 
kemampuan bank dalam menjaga resiko kegagalan pengembalian oleh debitur. ${ }^{9}$ NPF ini yang nantinya berimbas pada bank sebagai akibat dari timbulnya pembiayaan bermasalah, yang pada akhirnya hilangnya kesempatan bank untuk memperoleh pendapatan dari pembiayaan yang diberikan sehingga mengurangi perolehan laba atau dapat dikatakan pembiayaan mempengaruhi rentabilitas bank. Tingkat ratio NPF yang tinggi menandakan bahwa kondisi bank dalam keadaan tidak sehat, dan hal tersebut mencerminkan kinerja pada bank buruk.

Operational Efficiency Ratio (OER) atau Biaya Operasional terhadap pendapatan Operasional sangat perlu untuk dilihat. Kegiatan-kegiatan operasional bank haruslah dijalankan dengan baik, kegiatan operasional yang baik akan memperbaiki kinerja bank tersebut. Rasio OER atau disebut juga rasio efisiensi merupakan perbandingan antara total biaya operasi dengan total pendapatan operasi. ${ }^{10}$ OER itu sendiri digunakan untuk mengukur tingkat efisiensi dan kemampuan bank dalam melakukan kegiatan operasinya. Semakin rendah rasio ini, maka semakin efisien biaya operasional yang dikeluarkan oleh bank yang bersangkutan, sebaliknya semakin tinggi rasio OER maka menunjukkan semakin rendah kinerja bank tersebut. Oleh karena itu Bank Indonesia mememinta bank untuk menurunkan OER menjadi $80 \%$, karena semakin rendah tingkat rasio OER berarti semakin baik kinerja manajemen bank, karena lebih efisiensi dalam menggunakan sumber daya yang ada di perusahaan. ${ }^{11}$ Perkembangan peningkatan rasio keuangan perbankan syariah dapat dilihat pada tabel di berikut ini :

\section{Tabel 1}

Data rasio keuangan perbankan syariah

\begin{tabular}{|c|c|c|c|c|c|}
\hline & Periode & ROA & CAR & NPF & OER \\
\hline \multirow{9}{*}{$\stackrel{ }{\circ}$} & April & 1,1 & 16,98 & 4,82 & 92,34 \\
\hline & Mei & 1,11 & 16,88 & 4,75 & 92,26 \\
\hline & Juni & 1,1 & 16,42 & 4,47 & 90,98 \\
\hline & Juli & 1,04 & 17,01 & 4,5 & 91,56 \\
\hline & Agustus & 0,98 & 16,42 & 4,49 & 92,03 \\
\hline & September & 1 & 16,16 & 4,41 & 91,68 \\
\hline & Oktober & 0,7 & 16,14 & 4,91 & 94,16 \\
\hline & November & 0,73 & 16,46 & 5,27 & 94,05 \\
\hline & Desember & 0,63 & 17,91 & 4,77 & 94,91 \\
\hline
\end{tabular}

9 Farrashita Aulia dan Prasetiono, "Pengaruh CAR, FDR, NPF, dan BOPO Terhadap Profitabilitas (Return On Equity) Study Empiris Pada Bank Umum Syariah di Indoneia Periode Tahun 2009-2013" 5 (1) (2016) Volume 5, Nomor 1.

10 Nikmatus Sholihah dan Jaka Sriyana, "Profitabilitas Bank Syariah pada Kondisi Biaya Operasional Tinggi,"

\begin{tabular}{cccccc}
\hline \multirow{2}{*}{$\underset{\sim}{*}$} & Januari & 0,42 & 18,05 & 5,21 & 97,01 \\
\cline { 2 - 6 } & Februari & 0,74 & 18,62 & 5,21 & 93,81 \\
\cline { 2 - 6 } & Maret & 1,23 & 18,47 & 4,56 & 89,9 \\
\hline
\end{tabular}

*Satuan dalam bentuk \%

*Source : Bank Indonesia, 2018

Dari data rasio keuangan perbankan syariah di atas menunjukkan data berfluktuasi setiap bulannya dan juga hubungan masing-masing rasio terhadap return on asset teridentifikasi memiliki ketidaksesuaian dengan teori yang telah ada. Pada tabel di atas terlihat, ketika CAR mengalami peningkatan menjadi17,01\% di bulan juli 2017, justru ROA turun menjadi 1,04\%. Namun ketika ROA naik dari $0,74 \%$ di bulan februari menjadi $1,23 \%$ di bulan Maret justru CAR turun menjadi $18,47 \%$. Hal ini berbeda dengan teori yang menyatakan bahwa ketika ketika CAR naik maka ROA juga ikut naik. Di rasio yang lain, yaitu OER yang mengalami kejadian serupa. Ketika OER di bulan desember mengalami kenaikan menjadi 94,91 justru ROA turun menjadi 0,63. Namun sebaliknnya ketika ROA naik menjadi $1,23 \%$ justru OER justru turun, bahkan sangat drastis yang semula di bulan februari OER sebesar 93,81\% turun menjadi 89,9\%. Sedangkan kenaikan OER seharusnya linear dengan meningkatnya ROA. Pada rasio NPF, ketika NPF turun menjadi 4,47\% di bulan juni, akan tetapi ROA turun menjadi 1,1\% yang mana ROA di bulan mei sebesar 1,11\%. Hal ini tentunya berbeda dengan penjelasan sebelumnya, yang menyatakan bahwa hubungan diantar kedua ialah negatif. bukan malah sebaliknya.

Adanya gejala-gejala tersebut, maka perlu adanya penelitian lebih lanjut. Karena banyak bank syariah yang di converted dari bank konvensional, penelitian ini tertuju pada bank umum syariah yang dimiliki oleh negara atau Badan Usaha Milik Negara (BUMN), tepatnya yaitu Bank Mandiri Syariah, BNI Syariah, BRI Syariah dan BTN Syariah. Sejauh temuan peneliti, belum ada penelitian sebelumnya yang meneliti dengan subjek bank umum syariah yang khusus milik negara, dengan indikatorindikator rasio yang telah di paparkan di atas. Mengingat kelemahan yang melekat pada BUMN bahwasanya manajemen perusahaan tidak prosefional serta sulit memperoleh keuntungan, bahkan perusahaan sering kali merugi. Hal ini

Oktober

2015 , https://doi.org/10.13140/RG.2.1.2707.0164 UII, 2015. 11 Muhammad Fazlur Rachmad dalamm Lemiyana dan Erdah Litriani, "Pengaruh NPF, FDR, BOPO Terhadap Return On Asset pada Bank Umum Syariah" 2(1) (31 Desember 2016): 31-49 Volume 2, Nomor 1, 2016. 
menarik untuk ditelaah lebih lanjut mengenai bank tersebut. Sejauh mana sebenarnya kinerja dari bank syariah yang di miliki oleh BUMN dalam memanage serta seberapa besar pengaruhnya terhadap laba yang merupakan komposisi dari Return On Asset.

\section{Tinjauan Pustaka dan Pengembangan Hipotesis}

\section{A. Penelitian Terdahulu}

Penelitian yang dilakukan oleh peneliti merupakan sebuah penelitian keberlanjutan dari penelitian yang sejenis oleh peneliti-peneliti lain, namun berbeda objek dan subjek penelitian. Baik itu penambahan objek dan subjek maupun pengurangannya. Oleh peneliti ditemukan beberapa perbedaan hasil penelitian yang berbeda satu sama lain. Di antaranya sebagai berikut :

Capital Adequacy Ratio yang diteliti oleh Syamsurizal (2016) dengan penelitian berjudul "Pengaruh CAR (Capital Adequecy Ratio), NPF (Non Performing Financing) dan BOPO (Biaya Operasional Perpendapatan Operasional) Terhadap ROA (Return On Asset) Pada BUS (Bank Umum Syariah) yang terdaftar di BI (Bank Indonesia)". Hasil menunjukkan bahwa CAR memiliki pengaruh yang signifikan dan positif terhadap ROA. Penelitian oleh Sumarlin (2016) dengan judul "Analisis Pengaruh Inflasi, CAR, FDR, BOPO, dan NPF Terhadap Profitabilitas Perbankan Syariah", menunjukkan bahwa CAR berpengaruh secara signifikan dan negatif terhadap ROA. Sedangkan di penelitian yang lain, yang dilakukan oleh Nikmatus Sholihah dan Jaka Sriyana (2013) dengan judul penelitian "Profitabilitas Bank Syariah Pada Kondisi Biaya Operasional Tinggi" dengan objek yang diteliti adalah Bank Umum Syariah. Hasil penelitian menunjukkan bahwa CAR tidak berpengaruh secara signifikan dan positif terhadap ROA. Hasil penelitian yang sama juga ditunjukkan oleh Ningsukma Hakim dan Haqiqi Rafsanjani (2016) "Pengaruh Internal Capital Adequacy Ratio (CAR), Financing to Deposit Ratio (FDR), dan Biaya Operasional Per Pendapatan Operasional (BOPO) dalam peningkatan Profitbilitas Industri Bank Syariah di Indonesia" hasil penelitian bahwa CAR tidak berpengaruh secara signifikan dan positiff terhadap ROA.

Kemudian Non Perfoming Financing yang diteliti oleh Wibisono dan Salamah (2017) dengan penelitian berjudul "Pengaruh CAR, NPF, BOPO, FDR, Terhadap ROA yang dimediasi oleh NOM" menunjukkan bahwa NPF memiliki pengaruh yang signifikan dan positif terhadap ROA. Penelitian oleh
Okyviandi Putra Erlangga dan Imron Mawardi (2016) dengan judul "Pengaruh Total Aktiva, Capital Adequacy Ratio (CAR), Finance to Deposit Ratio, (FDR) dan Non Performing Financing (NPF) Terhadap Return On Asset (ROA) Bank Umum Syariah di Indonesia Periode 2010-2014" bahwa NPF berpengaruh secara signifikan dan negatif terhadap return on asset. Namun di satu sisi, berbeda dengan hasil penelitian oleh Linda Widyaningrum dan Dina Fitrisia Septiarini (2015) berjudul "Pengaruh CAR, NPF, FDR, dan OER Terhadap ROA Pada Bank Pembiayaan Rakyat Syariah di Indonesia Periode Januari 2009 hingga Mei 2014”. Hasil penelitian menunjukkan bahwa variabel NPF tidak berpengaruh secara signifikan dan positif terhadap ROA. Hasil yang sama juga diperoleh Andy Setiawan (2017) "Analisis Pengaruh Tingkat Kesehatan Bank Terhadap Return On Asset' bahwa NPF tidak berpengaruh secara signifikan dan negatif terhadap ROA.

Operational Efficiency Ratio yang diteliti oleh Yasir M. Pidu (2015) dengan penelitian berjudul "Pengaruh CR, DER, dan BOPO Terhadap ROA Koperasi di Kabupaten Bone Bolango". Hasil penelitian menunjukkan bahwa BOPO berpengaruh secara signifikan dan negatif terhadap ROA. Penelitian yang dilakukan oleh Ronny Chandra (2013) dengan judul "Analisis Pengaruh Capital Adequacy Ratio, Operational Efficiency, Non Performing Financing, Loan to Deposit Ratio Terhadap Return On Asset pada Bank BUMN di Indonesia" menujukkan bahwa variabel BOPO juga berpengaruh secara signifikan dan negatif terhadap ROA. Demikian juga dengan penelitian oleh Bambang Sudiyatno dan Jati Suroso (2010) dengan judul "Analisis Pengaruh Dana Pihak Ketiga, BOPO, CAR, dan LDR Terhadap Kinerja Keuangan Pada Sektor Perbankan yang GO Public di Bursa Efek Indonesia (BEI) (Periode 2005-2008)". Hasil penelitian menunjukkan bahwa BOPO berpengaruh secara signifikan dan negatif terhadap ROA.

Dari beberapa beberapa penelitian terdahulu yang oleh peneliti ambil, terdapat research gap dari penelitian sebelumnya. Oleh karena itu perlu dilakukan penelitian lanjutan mengenai dampak capital Adequacy ratio, non performing financing, operational effeciency ratio terhadap return on asset.

\section{B. Pengembangan Hipotesis}

Berikut ini kerangka pemikiran dan pengembangan hipotesis, sebagai berikut: 


\section{Gambar 1 \\ Kerangka pemikiran}

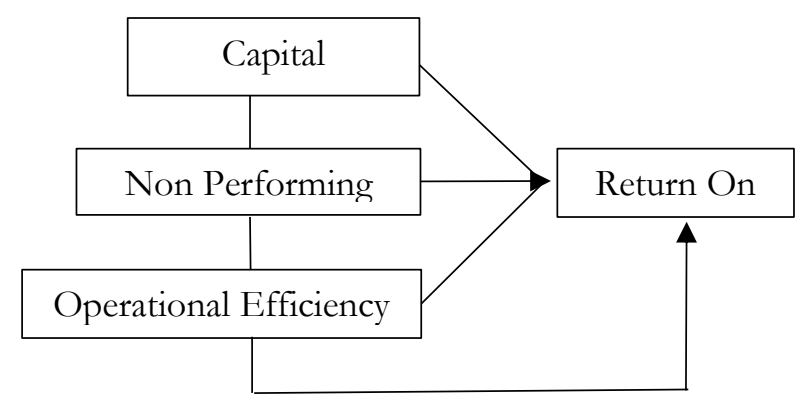

Dilihat dari kerangka pemikiran di atas, maka hipotesis yang dapat diajukan oleh peneilti sebagai jawaban sementara terhadap permasalahan penelitian ini disusun hipotesis sebagai berikut :

$\mathrm{H}_{1}$ : Capital Adequacy Ratio berpengaruh signifikan terhadap Return On Asset pada Bank Syariah Milik Negara.

$\mathrm{H}_{2}$ : Non Performing Financing berpengaruh signifikan terhadap Return On Asset pada Bank Syariah Milik Negara.

$\mathrm{H}_{3}$ : Operational Effeciency Ratio berpengaruh signifikan terhadap Return On Asset pada Bank Syariah Milik Negara.

\section{Landasan Teori}

Return On Asset menunjukkan kemampuan perusahaan menghasilkan laba dari aktiva yang dipergunakan, dimana rasio ini dihitung dengan cara membagi laba setelah pajak ${ }^{12}$ semakin tinggi return on asset menunjukkan kinerja perusahaan semakin baik, karena return yang semakin besar. Secara matematis ROA dapat dirumuskan sebagai berikut :

$$
\begin{aligned}
& \text { ROA }=\frac{\text { Laba Sebelum Pajak }}{\text { Rata-RataTotal Aset }} \times 100 \% \\
& \text { Capital Adequecy Ratio adalah rasio antara }
\end{aligned}
$$
modal terhadap aktiva. Rasio ini digunakan untuk mengukur proporsi modal sendiri dibandingkan dengan dana dari luar di dalam pembiayaan

12 Sugiyarso dalam Yasir M. Pidu, "Pengaruh CR, DER, dan BOPO terhadap ROA pada koperasi di Kabupaten Bone Bolango" 05 (01) (1 Februari 2015): 59-65 Volume 5, Nomor 1, 2015.

13 Muhammad, Manajemen Dana Bank Syariah (Jakarta: Rajagrafindo Persada, 2005), 249.

14 Veithzal Rivai, dkk dalam Syamsurizal, "Pengaruh CAR (Capital Adequacy Ratio), NPF (Non Performing Financing) dan BOPO (Biaya Operasional Perpendapatan Operasional) terhadap ROA (Return On Asset) pada BUS (Bank Umun Syariah) yang terdaftar di (Bank Indonesia)," Kutubkhanah Jurnal Penelitian Sosial Keagamaan, 19 (2) (Desember 2016), kegiataan usaha perbankan. Setiap bank wajib menjaga kecukupan modalnya untuk menjaga tingkat likuiditasnya. Bank yang sehat harus memiliki CAR paling sedikit sebesar 8\% permodalan terhadap aktiva berisiko. ${ }^{13}$ Semakin besar rasio ini maka semakin baik posisi modal bank. ${ }^{14}$ Secara matematis ROA dapat dirumuskan sebagai berikut :

$$
C A R=\frac{\text { Modal Bank }}{\text { Total ATMR }} \times 100 \%
$$

Non Performing Financinng merupakan rasio keuangan yang menunjukkan risiko pembiayaan yang dihadapi baik akibat pemberian pembiayaan dan investasi dana bank pada portofolio yang berbeda. Non Performing Financing ini digunakan untuk mengukur pembiayaan bermasalah. Risiko pembiayaan ini dapat terjadi akibat kegagalan atau ketidakmampuan nasabah dalam mengembalikan jumlah pinjaman yang diterima dari bank beserta bagi hasilnya sesuai dengan jangka waktu yang telah di tetapkan. ${ }^{15}$ Rasio ini merupakan cerminan dari pembiayaan bermasalah bank. Tinggi rasio ini menandakan kinerja keuangan bank tersebut buruk. Secara matematis ROA dapat dirumuskan sebagai berikut :

$$
\begin{gathered}
N P F=\frac{\text { Pembiayaan Bermasalah }}{\text { Total Pembiayaan }} \times 100 \% \\
\text { Operational Efficiency Ratio atau rasio efisiensi }
\end{gathered}
$$
adalah perbandingan antara biaya operasional dengan pendapatan operasional. Rasio ini digunakan untuk megukur tingkat efisiensi dan kemampuan bank dalam melakukan kegiatan operasionalnya. ${ }^{16}$ Semakin kecil rasio ini berarti semakin efisien biaya operasional yang dikeluarkan, sehingga kemungkinan bank dalam kondisi bermasalah semakin kecil. Secara matematis ROA dapat dirumuskan sebagai berikut

$$
O E R=\frac{\text { Biaya Operasional }}{\text { Pendapatan Operasional }} \times 100 \%
$$

http:/ /ejournal.uin-

suska.ac.id/index.php/Kutubkhanah/article/view/254 8. Volume 19, Nomor 2, 2016.

15 Mudrajad Kuncoro dalam Lemiyana dan Erdah Litriani, "Pengaruh NPF, FDR, BOPO Terhadap Return On Asset pada Bank Umum Syariah" Volume 2, Nomor 1, 2016.

${ }^{16}$ Lukman Dendawijaya dalam Syamsurizal, "Pengaruh CAR (Capital Adequacy Ratio), NPF (Non Performing Financing) dan BOPO (Biaya Operasional Perpendapatan Operasional) terhadap ROA (Return On Asset) pada BUS (Bank Umun Syariah) yang terdaftar di (Bank Indonesia)" Volume 19, Nomor 2, 2016. 


\section{Metode Penelitian}

\section{A. Jenis dan Sumber data}

Data yang digunakan dalam penelitian ini termasuk dalam jenis data Sekunder dengan kategori berupa data panel. Data panel merupakan gabungan dari data cross section dan time series, yang diperoleh dari situs resmi masing-masing bank yang telah di publish, berupa data rasio-rasio yang terdapat dalam laporan keuangan bank. Periode waktu data dari tahun 2014-2015 dengan pembagian kuartal setiap tahun. Masing-masing ialah situs resmi Bank Mandiri Syariah, BRI Syariah, BNI Syariah, dan BTN Syariah.

\section{B. Teknik Analisis}

Analisis penelitian dalam penelitian ini menggunakan model regresi data panel. Regresi dengan menggunakan data panel atau pooled data memiliki beberapa keunggulan dibandingkan dengan pendekatan standar cross section maupun time series. Di antaranya: ${ }^{17}$ Jumlah pengamatan yang lebih besar, meningkatkan degree of fredom, data memiliki variabilitas yang besar dan mengurangi kolinieritas antara variabel penjelas, yang mana dapat menghasilkan estimasi ekonometri yang efisien. Pooled data juga memberikan informasi lebih banyak bila dibandingkan dengan data cross section maupun time series. Serta memberikan penyelesaian yang lebih baik dalam inferensi perubahan dinamis dibandingkan data cross section. Teknik analisis ini digunakan untuk memperoleh informasi dalam mengetahui pengaruh capital adequacy ratio, non performing financing, dan operational effeciency ratio terhadap return on asset. Model persamaan regresi data panel yang merupakan gabungan dari data cross section dan data time series padapenelitian ini sebagai berikut :

$Y_{i t}=a+\beta_{1} X_{1 i t}+\beta_{2} X_{2 i t}+\beta_{3} X_{3 i t}+e_{i t}$ Keterangan :

Tabel 3 Hausman Test

\begin{tabular}{cccc}
\hline & & Chi- & \\
& Chi-Sq. & Sq. & \\
Test Summary & Statistic & d.f. & Prob. \\
\hline Period random & 6.786463 & 3 & 0.0790 \\
\hline
\end{tabular}

*Source : Data hasil olahan Eviews 7.0, 2018

$$
\begin{array}{ll}
Y_{i t} & : \text { Return On Asset } \\
\beta_{0} & : \text { Konstantan } \\
\beta_{1} X_{1 i t} & : \text { Capital Adequacy Ratio } \\
\beta_{2} X_{2 i t} & : \text { Non Performing Financing } \\
\beta_{3} X_{3 i t} & : \text { Operational Effeciency Ratio } \\
e & : \text { Variabel Pengganggu (Error) }
\end{array}
$$

\section{Hasil dan Pembahasan}

Sebelum memilih model untuk mengestimasi parameter model dengan data panel, terlebih dahulu menentukan model yang paling tepat di antara beberapa model yang di analisis, yaitu dengan menggunakan uji statistik $\mathrm{F}$ atau Chow test. Uji ini digunakan untuk mengetahui apakah teknik regresi data panel dengan metode Fixed Effect lebih baik dari pada model Cammon Effect dengan cara melihat nilai probabilitas $F$ statsitik. Apabila nilai probabilitas $\mathrm{F}$ statistik lebih kecil dari alpha 5\%. Maka model yang tepat untuk regresi data panel adalah model Fixed Effect. Sebaliknya Apabila nilai probabilitas F statistik lebih besar dari alpha sebesar $5 \%$ maka model yang tepat untuk regresi data panel adalah model Common Effect. Berikut hasil analisis Chow Test.

\section{Tabel 2}

Chow Test

\begin{tabular}{cccc}
\hline Effects Test & Statistic & d.f. & Prob. \\
\hline Cross-section F & 11.917647 & $(3,57)$ & 0.0000 \\
\hline $\begin{array}{c}\text { Cross-section } \\
\text { Chi-square }\end{array}$ & 31.160841 & 3 & 0.0000 \\
\hline *Source : Data hasil olahan Eviews & $7.0,2018$
\end{tabular}

Dari hasil analisis di peroleh nilai probabilitas chi-square adalah 0,0000 yang mana lebih kecil dari alpha sebesar 0,05. Artinya model yang terbaik yang dapat dipilih ialah model Fixed Effect. Karena model Fixed Effect dianggap lebih baik, maka selanjutnya membandingkan antara model Fixed Effect dengan model Random Effect. Untuk mengetahui mana model yang tepat untuk dipilih, digunakan Hausman Test. Berikut hasil uji Hausman :

Uji Hausman dapat dilihat pada nilai probabilitasnya. Apabila nilai probabilitas lebih kecil dari alpha 5\%. Maka model yang tepat untuk regresi data panel adalah model Random Effect. Sedangkan jika nilai probabilitas lebih besar dari alpha sebesar 5\%, Maka model yang tepat dipilih adalah model Fixed Effect.

Pada uji Hausman di atas, diperoleh nilai probabilitas sebesar 0,0790. Hal ini menandakan

17 Hsiao (1995) dalam Nikmatus Sholihah dan Jaka Sriyana, "Profitabilitas Bank Syariah pada Kondisi Biaya Operasional Tinggi." 
bahwa nilai Prob. $>0.05$. artinya model yang tepat dipilih dalam hal ini ialah model Fixed Effect. Model ini yang digunakan untuk mengestimasi pengaruh variabel bebas terhadap variabel terikat. Berikut hasil analisis model Fixed Effect :

Tabel 4

Fixed Effect Model

\begin{tabular}{ccccc}
\hline Variable & Coefficient & Std. Error & t-Statistic & Prob. \\
\hline Period random & 6.786463 & 3 & 0.0790 & \\
\hline C & 9.270724 & 0.415602 & 22.30675 & 0.0000 \\
\hline CAR? & -0.005285 & 0.005057 & -1.045154 & 0.3004 \\
\hline NPF? & 0.025256 & 0.017113 & 1.475865 & 0.1455 \\
\hline OER? & -0.091416 & 0.004254 & -21.48926 & 0.0000 \\
\hline
\end{tabular}

*Source : Data hasil olahan Eviews 7.0, 2018

Berdasarkan hasil analisis uji parsial di atas, di peroleh nilai probabilitas variabel CAR sebesar 0.3004. Hasil tersebut menunjukkan bahwa nilai Prob $>0,05$, dan hipotesis $\mathrm{H}_{1}$ ditolak. Artinya bahwa variabel CAR tidak berpengaruh secara signifikan terhadap ROA. Pada variabel NPF diperoleh nilai probabilitas sebesar 0,1455. Nilai menunjukkan bahwa nilai Prob $>0,05$, dan hipotesis $\mathrm{H}_{2}$ ditolak Artinya bahwa variabel NPF tidak memiliki pengaruh yang signifikan terhadap ROA. dan kemudian pada variabel terakhir yaitu variabel OER di peroleh nilai probabilitas sebesar 0,0000 . Nilai tersebut menunjukkan bahwa nilai Prob $<0,005$, dan hipotesis $\mathrm{H}_{3}$ diterima. Artinya bahwa variabel OER berpengaruh secara signifikan terhadap ROA.

Tabel 5

Simultan Test dan Koefisien Determinasi

\begin{tabular}{llll}
\hline R-squared & 0.969579 & Mean dependent var & 1.038281 \\
\hline Adjusted R-squared & 0.966377 & S.D. dependent var & 0.457219 \\
\hline S.E. of regression & 0.083839 & Akaike info criterion & -2.016920 \\
\hline Sum squared resid & 0.400651 & Schwarz criterion & -1.780792 \\
\hline Log likelihood & 71.54143 & Hannan-Quinn criter. & -1.923897 \\
\hline F-statistic & 302.7817 & Durbin-Watson stat & 0.917069 \\
\hline Prob(F-statistic) & 0.000000 & & \\
\hline
\end{tabular}

Berdasarkan hasil analisis di atas di peroleh nilai probabilitas F statistik sebesar 0,000000. Karena nilai probabilitas $<0.05$. dengan demikian, secara simultan variabel CAR, NPF, dan OER berpengaruh terhadap ROA.

Uji Koefisien Determinasi diperolehan nilai pada adjusted $R^{2}$ sebesar 0,966377, hal ini menunjukkan bahwa 97\% variabel ROA dapat dijelaskan oleh tiga variabel bebas di atas. Sedangkan sisanya sebesar 3\% dijelaskan oleh sebab-sebab lain di luar model yang merupakan kontribusi variabel bebas lain di luar ketiga variabel dalam penelitian ini.

Dari tabel 4 output Fixed Effect Model di atas juga diperoleh hasil estimasi persamaan model regresi sebagai berikut :

$$
\begin{aligned}
R O A=9,270724 & -C A R_{0,005285} \\
& +N P F_{0,025256}-O E R_{0,091416}
\end{aligned}
$$

Estimasi persamaan model di atas menggambarkan bahwa Pada variabel CAR diperoleh coefficient value sebesar -0,005285 dan nilai koefisien tersebut bertanda negatif, artinya kenaikan rasio CAR sebesar $1 \%$ maka akan menurunkan ROA sebesar 0,5285\%. Coefficient value variabel NPF diperoleh sebesar 0,025256, artinya jika setiap NPF naik 1\% maka akan menurunkan ROA sebesar $2.5256 \%$. Coefficient value variabel OER diperoleh sebesar -0,091416 dan juga nilai koefisien tersebut bertanda negatif, artinya jika setiap kenaikan OER sebesar 1\% maka akan menurunkan ROA sebesar 9,1416\%.

\section{Kesimpulan}

Dari hasil pembahasan dan analisis data yang telah dilakukan, dapat disimpulkan bahwa secara parsial bahwa capital adequacy ratio dan non performing ratio tidak memiliki pengaruh signifikan terhadap return on asset. Sedangkan operational effeciency ratio memiliki pengaruh yang signifikan terhadap return on asset. Meskipun begitu, nilai koefisiensi dari variabel capital adequacy ratio dan non performing financing menunjukkan bahwa tidak adanya terdapat 
kesesuaian antara teori dan hasil yang di dapatkan. Hanya variabel operational effeciency ratio yang sejalan dengan teori. Masing-masing dalam teori dijelaskan, ketika capital adequacy ratio naik maka akan meningkatkan return on asset. Namun hasil yang diperoleh sebaliknya, setiap kenaikan capital adequacy ratio $1 \%$ justru menurunkan return on asset sebesar $0,5285 \%$. Hasil koefisien non performing financing juga sebaliknya. Yang mana seharusnya ketika non performing naik maka return on asset turun. Namun nilai koefiesien menghasilkan berbeda, kenaikan non performing financing sebesar $1 \%$ justru return on asset naik sebesar 2,5256\%. Kemudian operational effeciency ratio yang seharusnya kenaikannya akan menurunkan return on asset. justru hasil berbeda yang diperoleh yaitu peningkatan operational effeciency ratio sebesar 1\% maka menurunkan return on asset sebesar 9,1416\%.

\section{Daftar Pustaka}

Darmono. Manajemen Keuangan, Berbasis Balanced Scorecard, Pendekatan Teori, Kasus, dan Riset Bisnis. Kedua. Jakarta: Bumi Aksara, 2011.

Farrashita Aulia, dan Prasetiono. "Pengaruh CAR, FDR, NPF, dan BOPO Terhadap Profitabilitas (Return On Equity) Study Empiris Pada Bank Umum Syariah di Indoneia Periode Tahun 2009-2013" 5 (1) (2016).

Ikatan Bankir Indonesia (IBI). Manajemen Kesehatan Bank Berbai Resiko. Pertama. Jakarta: Gramedia Pustaka Utama, 2016.

Khotibul Umam. Perbankan Syariah, Dasar-dasar dan Dinamika Perkembangannya di Indoensia. Jakarta: Rajagrafindo Persada, 2016.

Lemiyana, dan Erdah Litriani. "Pengaruh NPF, FDR, BOPO Terhadap Return On Asset pada Bank Umum Syariah" 2(1) (31 Desember 2016): 31-49.

Lina Nur Hidayat. "Pengaruh Kecukupan Modal (CAR), Pengelolaan Kredit (NPL), dan Likuiditas Bank (LDR) Terhadap Probabilitas Kebangkrutan Bank (Studi Pada Bank Umum Swasta Devisa Yang Tercatat di BEI Tahun 2009-2013)" 12 (1) (t.t.).

Muhammad. Manajemen Dana Bank Syariah. Jakarta: Rajagrafindo Persada, 2005.

Nikmatus Sholihah, dan Jaka Sriyana. "Profitabilitas Bank Syariah pada Kondisi Biaya Operasional Tinggi," Oktober 2015. https://doi.org/10.13140/RG.2.1.2707.0 164.

Nur Yasin. Hukum Ekonomi Islam. Malang: UIN Malang Press, t.t.
Sofyan Syafri Harahap. Analisis Kritis Atas Laporan Kenangan. Jakarta: Rajagrafindo, 2007.

Suryani. "Analisis Pengaruh Financing To Deposit Ratio (FDR) Terhadap Profitabilitas Perbankan Syariah di Indonesia" 19 (1) (Mei 2011): 47-74. http://dx.doi.org/10.21580/ws.19.1.212.

Syamsurizal. "Pengaruh CAR (Capital Adequacy Ratio), NPF (Non Performing Financing) dan BOPO (Biaya Operasional Perpendapatan Operasional) terhadap ROA (Return On Asset) pada BUS (Bank Umun Syariah) yang terdaftar di (Bank Indonesia)," Kutubkhanah Jurnal Penelitian Sosial Keagamaan, 19 (2) (Desember 2016). http://ejournal.uinsuska.ac.id/index.php/Kutubkhanah/arti cle/view/2548.

Yasir M. Pidu. "Pengaruh CR, DER, dan BOPO terhadap ROA pada koperasi di Kabupaten Bone Bolango" 05 (01) (1 Februari 2015): 59-65. 